\title{
Geochronology of 210Pb in sediments of Sepang Besar River, Malaysia
}

\begin{abstract}
Geochronological studies to determine pattern and rate of sediment deposition is still lacking in Malaysia. The aim of this study is to investigate geochronological pattern of $210 \mathrm{~Pb}$ in core sediments of the Sepang Besar River. Sediment cores were collected from rivermouth, middle course and upper course of the river. Sediment cores were cut at $2 \mathrm{~cm}$ interval for each layer, treated with established method and analyzed by beta spectrometry. Results showed the activities of $210 \mathrm{~Pb}$ along Sepang Besar River varied at a wide range. Significantly lower $210 \mathrm{~Pb}$ activity was found at the rivermouth as compared to middle and upper courses of Sepang Besar River. This could be due to the geology of the watershed and chemical weathering conditions around the area.
\end{abstract}

Keyword: Geochronology; 210Pb; Core sediment; Beta spectrometry; Sepang Besar River 